\title{
Goniadella bobrezkii (Annenkova, 1929) (Annelida, Polychaeta): first record in the Italian waters
}

\author{
Emanuele Mancini ${ }^{1}$, Francesco Tiralongo ${ }^{2}$, Daniele Ventura ${ }^{3}$, Andrea Bonifazi $^{4}$
}

1 Laboratory of Experimental Oceanology and Marine Ecology, University of Tuscia, Molo Vespucci, Porto Commerciale di 00053 Civitavecchia, Roma, Italy. 2 University of Catania, Department of Biological, Geological and Enviromental Science, Catania 95124, Italy. 3 Department of Enviromental Biology, University of Rome "La Sapienza", V. le dell' Università 32, 00185 Rome, Italy. 4 Laboratory of Experimental Ecology and Aquaculture, Tor Vergata University, Via della Ricerca Scientifica, 00133 Rome, Italy.

Corresponding author: Emanuele Mancini, e.mancini@unitus.it

\begin{abstract}
Goniadella bobrezkii (Annenkova, 1929) is a small goniadid worm identifiable by the number of anterior uniramous parapodia and by the position of the posterior spine-like notochetae arising dorsal to dorsal cirri. Although it was already reported in the Mediterranean Sea, it has never been found in the Italian waters. This study represents the first generic and specific record of G. bobrezkii along Italian coasts. A total of 25 specimens were collected in a Posidonia oceanica (L.) Delile bed, depth of $7 \mathrm{~m}$, off Civitavecchia (Rome).
\end{abstract}

\section{Key words}

Goniadidae, Italian waters, Mediterranean Sea, Posidonia oceanica bed.

Academic editor: Sergio N. Stampar | Received 29 September 2018 | Accepted 19 December 2018 | Published 1 February 2019

Citation: Mancini E, Tiralongo F, Ventura D, Bonifazi A (2019) Goniadella bobrezkii (Annenkova, 1929) (Annelida, Polychaeta): first record in the Italian waters. Check List 15 (1): 125-130. https://doi.org/10.15560/15.1.125

\section{Introduction}

The family Goniadidae Kinberg, 1866 (Annelida, Phyllodocida) includes 11 genera and 73 species (Read and Fauchald 2018a). The members of this family are represented by errant polychaetes occurring from intertidal to abyssal depths (Böggemann 2005). The goniadids are characterized by an annulated conical prostomium ending in 2 pairs of appendages, and by a long eversible pharynx densely covered by papillae. The proboscis is armed with 2 types of paragnaths (macro- and micrognaths), arranged in a dorsal and in a ventral arc, and they may also have 2 lateral rows of horizontal V-shaped chevrons near pharynx base. The body of the goniadids is usually divided into an anterior region, with uniramous parapodia, and a following region with biramous or sub-biramous parapodia (Böggemann 2005, Böggemann and Purschke 2006).

The goniadids are cosmopolitan, burrowing, predatory worms, and along the European coasts, 13 species are reported belonging to 4 genera: Glycinde, Goniada, Goniadella, and Progoniada (Costello et al. 2001). In the Italian waters, only 2 genera and 4 species are currently reported (Castelli et al. 2008): Glycinde nordmanni (Malmgren, 1866), Goniada emerita Audouin \& H Milne-Edwards, 1833, Goniada maculata Örsted, 1843, and Goniada norvegica Örsted, 1845. Some specimens belonging to a new (as yet undescribed) species of the genus Progoniada Hartman, 1965 were recorded in the South Adriatic Sea (Gambi and Giangrande 1988). However, Rizzo and Amaral (2004) indicated that the 


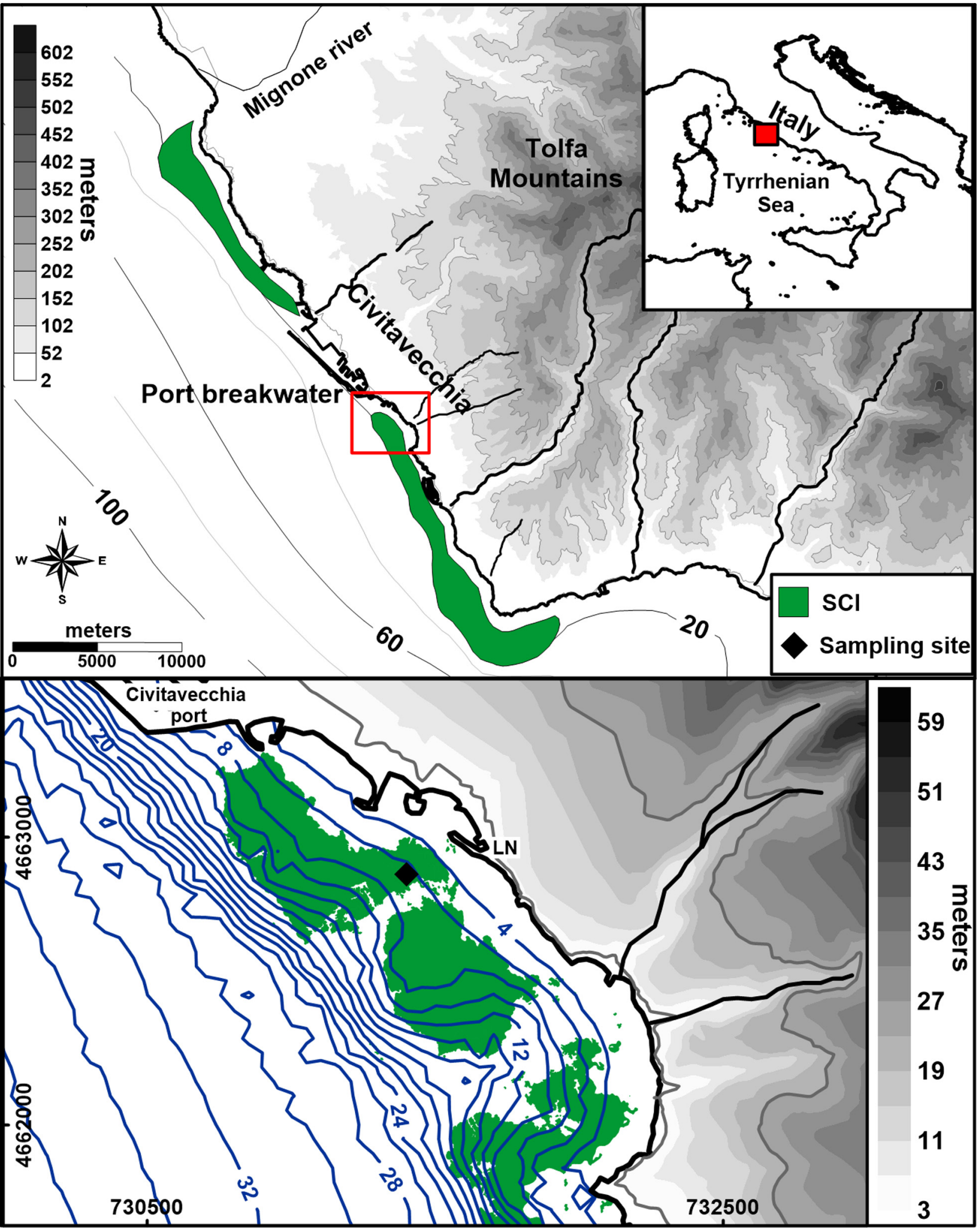

Figure 1. Map of the study area with location of sampling site (SCl: Site of Community Importance "Posidonia oceanica meadows").

examined specimen could be a juvenile of Goniada sp., because although it had only uniramous chaetigers, the sub-biramous chaetigers might not yet have developed.

Within the Goniadidae, Goniadella Hartman, 1950 is recognizable by the presence of uniramous anterior parapodia followed by a region with sub-biramous parapodia. Their notochaetae are acicular, whereas neurochaetae include compound falcigers and spinigers in all parapodia (Böggemann 2005, Faulwetter et al. 2017). Currently, this genus comprises 8 species with 4 reported for European waters (Costello et al. 2001): Goniadella bobrezkii (Annenkova, 1929), G. galaica (Rioja, 1923), G. gracilis (Verrill, 1973), and G. unicirra Agirrezabalaga, 1980. Goniadella bobrezkii is a small worm with body up to $30 \mathrm{~mm}$ long, bearing more than 100 chaetigers. This species is identifiable by the 
number of uniramous anterior parapodia (21-24) and by the position of the acicular notochaetae arising dorsal to dorsal cirri (Böggemann 2005). In European waters, $G$. bobrezkii which was originally described from the Black Sea (Annenkova 1929, Böggemann 2005), has been found in the North Sea and along the North East Atlantic coasts (France and Spain) (Wolff and Stengega 1975, Kirkegaard 2001, Böggemann 2005, Read and Fauchald 2018b), whereas, for the Mediterranean it has been reported only in Greece (Arvanitidis 2000, Faulwetter et al. 2017). During SCUBA surveys performed in 2015 and 2016, the goniadid G. bobrezkii was collected from a shallow-water bed of Posidonia oceanica (L.) Delile off Civitavecchia, Central Tyrrhenian Sea. This study represents the first generic and specific record of Goniadella bobrezkii for Italian waters.

\section{Methods}

Specimens of Goniadella bobrezkii were collected off Civitavecchia (Rome), near the harbor (Fig. 1). Sampling SCUBA surveys were performed during 2015 and 2016 in different months (October, March, May and August) on some sandy pools located among shallow waters in Posidonia oceanica meadow. Samples were collected by means of corers. After Gambi et al. (1998) and Buia et al. (2003), each PVC tube corer was $10 \mathrm{~cm}$ in diameter and $25 \mathrm{~cm}$ long (surface area $=78.5 \mathrm{~cm}^{2}$ ), with a $0.4 \mathrm{~mm}$ mesh net on top. Corers were plunged into the sediment to a depth of $20 \mathrm{~cm}$. At each sampling date, 5 replicates were collected and each sample was sieved with a mesh size of $0.5 \mathrm{~mm}$, the retained fraction of sediment was preserved in $4 \%$ buffered formalin. In the laboratory, all organisms were sorted and identified to the finest taxonomic level possible (i.e. species), and subsequently preserved in $75 \%$ ethanol. The morphological features and the diagnostic characteristics of G. bobrezkii specimens were examined following Hartman (1950) and Böggemann (2005). The material was deposited in the marine invertebrate collection of Laboratory of Experimental Oceanology and Marine Ecology, University of Tuscia (Civitavecchia, Roma).

\section{Results}

New records. Italia: Civitavecchia (Roma) $\left(42.0844^{\circ} \mathrm{N}\right.$, $11.7990^{\circ}$ E, 7 m deep), Emanuele Mancini, October 2015 (1 specimen), March 2016 (2 specimens), May 2016 (7 specimens), August 2016 (15 specimens).

Environmental characteristics. At the study site, the bed of $P$. oceanica occurs at depths between $3 \mathrm{~m}$ and about $18 \mathrm{~m}$, and its architecture shows a fragmented coverage that is characterised by the presence of several circular sandy patches and mixed rocks. Living $P$. oceanica covered $69 \%$ of the bottom, and its density did not vary over the year, remaining quite constant (260-312 shoots $\mathrm{m}^{-2}$ ) (Paladini De Mendoza et al. 2018). In the sampling site, the bed sediment is composed by gravelly coarse sand; the gravel fraction (19-60\%) mainly consisted in bioclasts composed by skeletal fragments and shells. The coastal site has moderate to high wave conditions with seasonal oscillation of wave intensity, with the maximum intensity in autumn and winter (1.5-3 m) and minimum in summer $(0.5-1.5 \mathrm{~m})$ (Paladini De Mendoza et al. 2018).

Identification. The specimens were assigned to the genus Goniadella based on the following morphological characteristics: prostomium annulated with 8 rings; trior quadriarticulated appendages on tip; proboscis with a few different types of papillae and with macrognaths and dorsal and ventral micrognaths; chevrons present; first segment with only a pair of small lateral cirri; anterior chaetigers with uniramous parapodia, following chaetigers with biramous or sub-biramous parapodia. Notochaetae acicular in anterior to posterior parapodia; neurochaetae compound falcigers and spinigers on all parapodia (Böggemann 2005). The specimens were subsequently identified as $G$. bobrezkii on the basis of the number of uniramous anterior parapodia (21-24) and of the position of the posterior acicular notochetae arising dorsal to dorsal cirri (Hartman 1950, Böggemann 2005).

Diagnosis. The 25 collected specimens were $8.5-14.8$ $\mathrm{mm}$ long with 77-103 setigers and biannulated segments that appear triannulate in the median part of dorsum. Body colorless or pale yellow after preservation (Fig. 2A). Conical prostomium with 8 rings endings in 4 triarticulated appendages (Fig. 2B). Pair of basal subdermal eyes (first ring) and a pair of subdistal eyes (third or fourth ring) are present. Proboscis with irregularly arranged papillae with higher density in the dorsal and terminal part. Subtriangular-shaped dorsal papillae and subquadrangular-shaped smaller and bifid ventral papillae. Each side of the proboscis bears 12-19 chevrons characterized by pointed tip and long slender arms (Fig. 2C). Macrognaths tridentate; micrognaths compound, 12-15 H+v/w dorsal and $3 \mathrm{H}+\mathrm{w}$ ventral (Fig. 2D). First segment achaetous and apodous, which has only 2 small lateral cirri (Fig. 2A). The parapodia are uniramous in the first 21-24 chaetigers (Fig. 3A); dorsal and ventral cirri subequal, conical, tapered; neuropodia with long conical prechaetal lobe and short rounded postchaetal lobe. The posterior region shows subbiramous parapodia that are slender and more digitiform than anterior ones (Fig. 3B). Dorsal part of the parapodia with 2 straight, acicular notochaetae with pointed tips arising over dorsal cirri (Fig. 3B-D). The neurochaetae are compound with articles of different length (Fig. 3C).

During the year, no significant variation in the morphological features and in the diagnostic characteristics of the specimens were observed.

Most of the specimens were collected in August and May, months characterised by maximum leaf length of $P$. oceanica and minimum wave intensity. Conversely, only 3 individuals were collected in the cold months, 

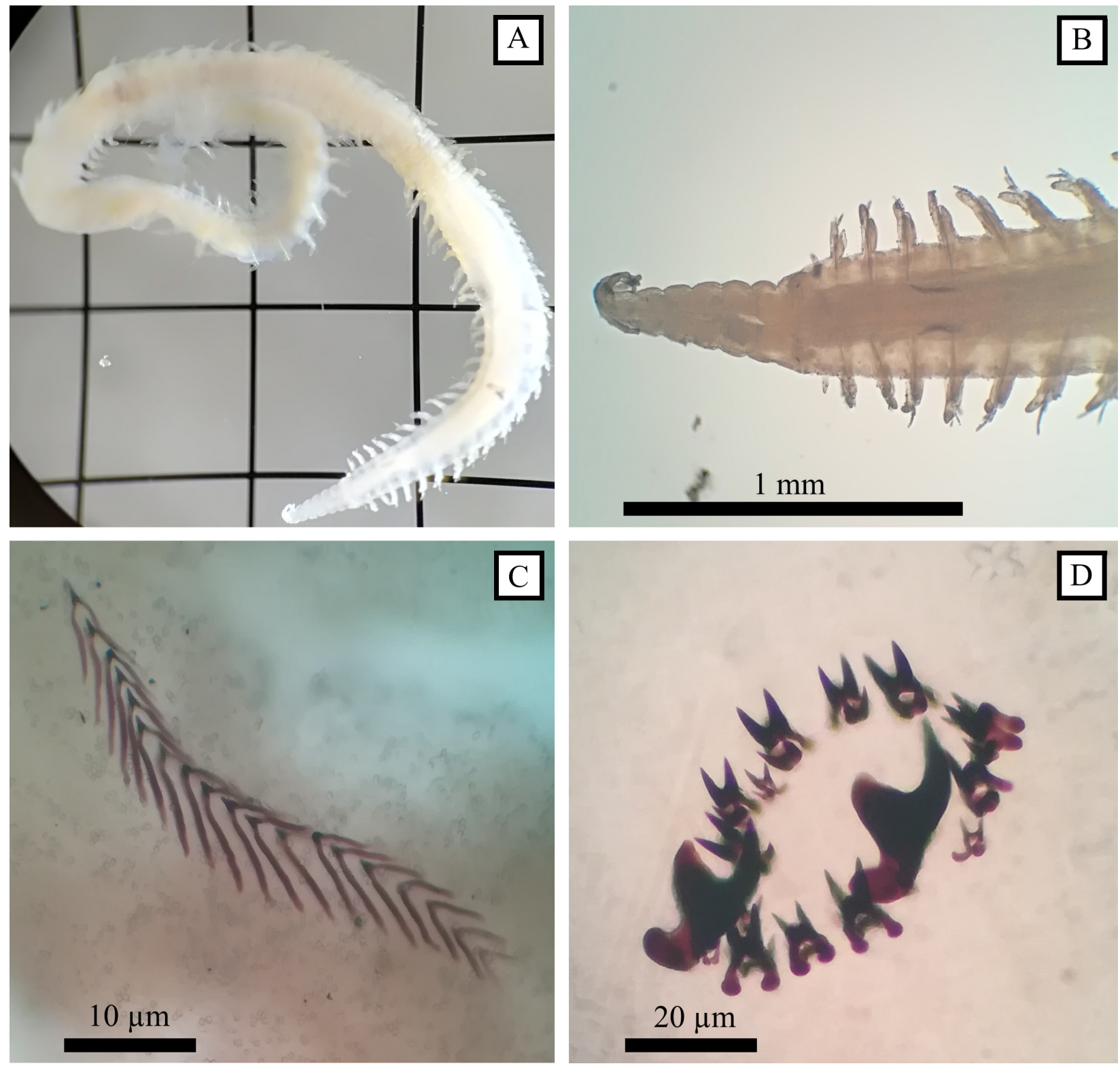

Figure 2. Goniadella bobrezkii. A. Dorsal view of whole animal. B. Dorsal view of anterior region. C. Chevrons. D. Rings of macrognaths and micrognaths.

when the sediment resuspension was maximum. The analysis of the macrozoobenthic fauna associated with the sandy patches revealed that polychaetes were the dominant taxon, mostly represented by the onuphid Aponuphis brementi (Fauvel, 1916), and by the phyllodocid Pseudomystides limbata (de Saint-Joseph, 1888). In addition, the detritivorous amphipod Gammarella fucicola (Leach, 1814), and the ophiuroid Amphipolis squamata (Della Chiaje, 1828) were also well represented in the benthic community.

\section{Discussion}

This study represents the first record of Goniadella bobrezkii (as well as the first record of the genus Goniadella) in the Italian coastal waters and the second record of this species in the Mediterranean waters. According to the literature, in the Mediterranean Sea, the species has been only reported in Greek waters (Arvantidis 2000, Costello et al. 2001, Faulwetter et al. 2017). In the European waters, this species is commonly distributed in the Black Sea (Annenkova 1929, Böggemann 2005) and around the North Eastern Atlantic coasts, England, France, Belgium and North Sea (Wolff and Stengega 1975, Kirkegaard 2001, Böggemann 2005, Read and Fauchald 2018b).

Goniadella bobrezkii shows some morphological similarities with the congeneric species G. galaica (Rioja, 1923), as described by Gil (2011) and remarked by Moreira and Parapar (2015), but G. galaica was only reported in the Galicia and in the Atlantic coast of Portugal. As suggested by above-mentioned authors, a direct comparison between the 2 species is necessary to determine their effective synonymy and their correct distribution in the European waters.

In our specimens, no significant variation in the 

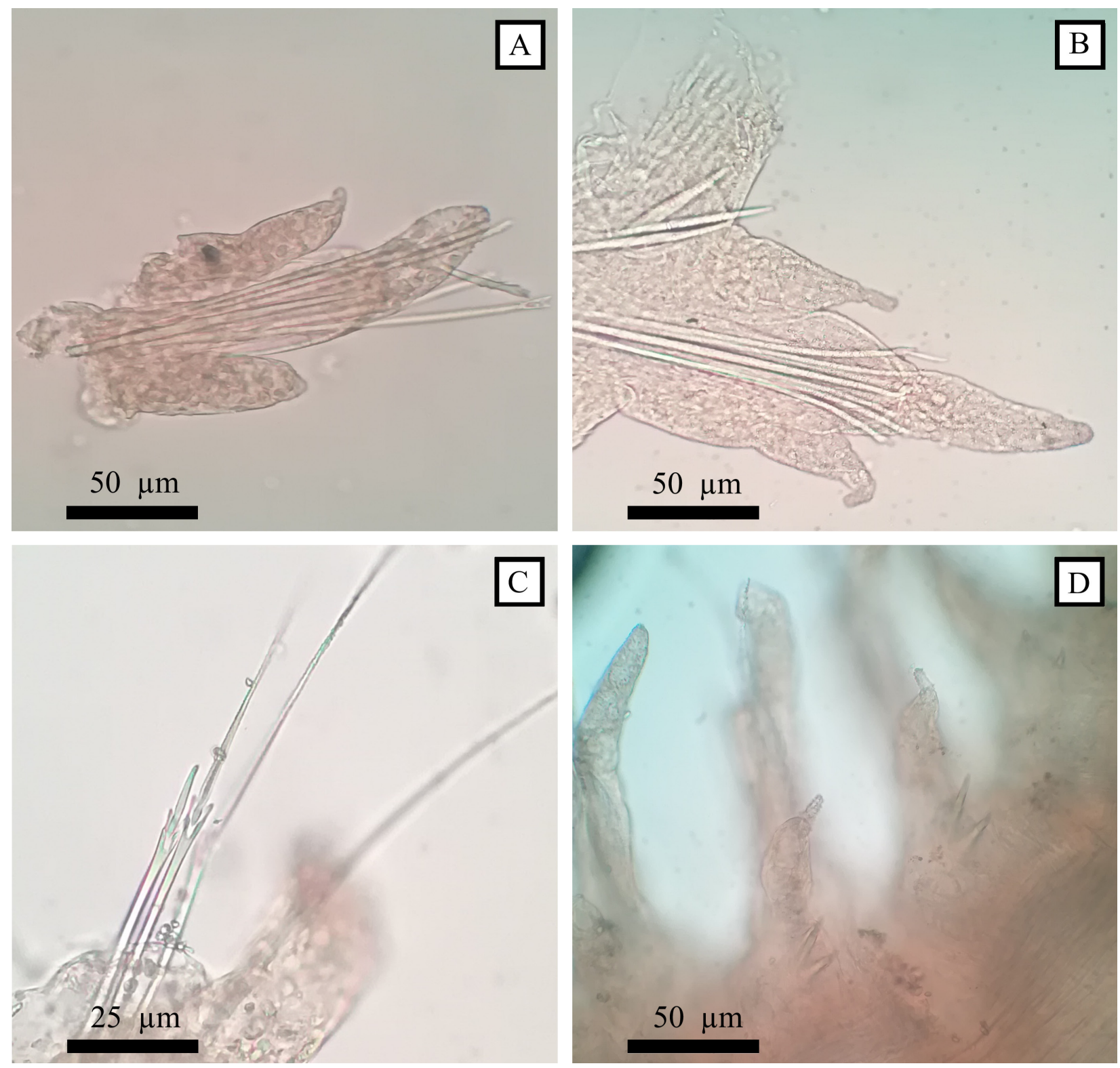

Figure 3. Goniadella bobrezkii. A. Anterior parapodium. B. Posterior parapodium. C. Chaetae. D. Dorsal view of posterior parapodia.

morphological features and in the diagnostic characteristics of the specimens was observed during the year, while the analysis of the abundance revealed an increase in the number of individuals from October to August. However, the lack of variation in morphological features could be related to the selectivity of the mesh size used during the sampling, which failed to retain intermediate and juvenile stages.

As for the ecology of $G$. bobrezkii, our work represents the first record of this species in association with the shallow water $P$. oceanica beds. In previous studies (Arvanitidis 2000, Böggemann 2005), this species has always been related to sandy substrates (fine, medium coarse sand and coarse sand with gravel). In agreement, our individuals were collected on gravelly coarse sand with high percentage of shells and skeletal fragments.

This work increases the knowledge about the distribution and ecology of this species, highlighting the need for a re-analysis of available collections in order to better clarify the taxonomic status of the genus Goniadella and consequently the real geographical distribution of $G$. bobrezkii.

\section{Acknowledgements}

We are thankful to Dr Francesco Paladini De Mendoza for his support during the sampling operations and for his contribution in the analysis and description of the environmental characteristics of the study area.

\section{Authors' Contributions}

EM collected (scuba diver) and identified the specimens, wrote the manuscript and prepared the map. FT collected (scuba diver) the specimens and wrote the manuscript. DV photographed (stereo and optical microscope) the specimens and revised the manuscript. AB examined the specimens, wrote, revised and approved the manuscript. 


\section{References}

Annenkova N (1929) Nachtrag zur Polychaetenfauna des Schwarzen Meeres, 1. Goniada bobrezkii sp. n. Doklady Rossiiskoi Akademii Nauk/Comptes Rendus de l'Academie des Sciences de Russie 1929: 495-497.

Arvanitidis C (2000) Polychaete fauna of the Aegean Sea: inventory and new information. Bulletin of Marine Science 66 (1): 73-96.

Böggemann M (2005) Revision of the Goniadidae. Abhandlungen des Naturwissenschaftlichen Vereins in Hamburg (Neue Folgen) 39: 1-354. https://doi.org/10.1111/j.1439-0469.2006.00395.x

Böggemann M, Purschke G (2006) Ultrastructure of the proboscidial papillae in some Goniadidae species (Annelida: "Polychaeta"). Cahiers de Biologie Marine 47 (2): 157.

Buia MC, Gambi MC, Dappiano M (2003) I sistemi a fanerogame marine. Biologia Marina Mediterranea 10: 145-198.

Castelli A, Bianchi CN, Cantone G, Çinar ME, Gambi MC, Giangrande A, Iraci Sareri D, Lanera P, Licciano M, Musco L, Sanfilippo R, Simonini R (2008) Annelida Polychaeta. Checklist della flora e della fauna dei mari italiani. Biologia Marina Mediterranea 15: 323-373.

Costello MJ., Emblow CS, White R (2001) European register of marine species. A check-list of the marine species in Europe and a bibliography of guides to their identification. Patrimoines Naturels 50 $1-463$.

Faulwetter S, Simboura N, Katsiaras N, Chatzigeorgiou G, Arvanitidis C (2017) Polychaetes of Greece: an updated and annotated checklist. Biodiversity Data Journal 5: e20997. https://doi.org/10. 3897/bdj.5.e20997

Gambi MC, Giangrande A (1988) Record of the genus Progoniada (Polychaeta: Goniadidae) in the Mediterranean Sea. Atti della Societa Toscana di Scienze Naturali, Residente in Piza, Serie B, Memorie 95: 147-154.

Gambi MC, Conti G, Bremec CS (1998) Polychate distribution, diversity and seasonality related to seagrass cover in shallow bottoms of the Tyrrhenian Sea (Italy). Scientia Marina 62 (1-2): 1-17. https://doi.org/10.3989/scimar.1998.62n1-21

Gil j (2011) The European Fauna of Annelida Polychaeta (Especialidade: Biodiversidade). PhD dissertation, Universidade de Lisboa, Lisboa, 1554 pp.

Hartman O (1950) Goniadidae, Glyceridae and Nephtyidae. Allan Hancock Pacific Expeditions 15: 1-181.

Kirkegaard J (2001) Polychaetes of the families Glyceridae, Goniadidae, and Nereididae from the North Atlantic around Iceland. Sarsia 86 (1): 13-20. https://doi.org/10.1080/00364827.2001.10420457

Moreira J, Parapar J (2015) Familia Gonadidae Kinberg, 1865. In: Parapar J, Moreira J, Núňez J, Barnich, R, Brito M, M del C, Fiege D, Capaccioni-Azzati R, El-Haddad M (Eds) Annelida Polychaeta IV. Fauna Ibérica 41. Consejo Superior de Investigaciones Cientificas, Madrid, 52-87.

Paladini De Mendoza F, Fontolan G, Mancini E, Scanu E, Scanu S, Bonamano S, Marcelli M (2018) Sediment dynamics and resuspension processes in shallow-water Posidonia oceanica meadows. Marine Geology 404: 174-186. http://doi.org/10.1016/j.mar geo.2018.07.006

Read G, Fauchald K (2018a) World Polychaeta database. Goniadidae Kinberg, 1866. World Register of Marine Species. http://www. marinespecies.org/aphia.php? $\mathrm{p}=$ taxdetails\&id=953. Accessed on: 2018-10-1.

Read G, Fauchald K (Ed.) (2018b) World Polychaeta database. Goniadella bobrezkii (Annenkova, 1929). World Register of Marine Species. http://www.marinespecies.org/aphia.php?p=taxdetails\& $\mathrm{id}=130143$. Accessed on 2018-10-1.

Rizzo AE, Amaral ACZ (2004) Progoniada and Goniadella (Annelida: Polychaeta: Goniadidae) from the outer continental shelf and slope off south-eastern Brazil. Journal of the Marine Biological Association of the United Kingdom 84(1): 47-58.

Wolff W, Stengega H (1975) Hesionura augeneri, Goniadella bobretzkii, and Parapodrilus psammophilus (Annelida, Polychaeta): new to the Netherlands. Zoologische Bijdragen 17 (12): 82-88. 